\title{
PENINGKATAN PERILAKU PENCEGAHAN DAMPAK PESTISIDA PADA KESEHATAN PETANI
}

\author{
Gracia Victoria Souisa*, Bellytra Talarima, Zasendy Rehena \\ Program Studi Kesehatan Masyarakat, Universitas Kristen Indonesia Maluku, Maluku, Indonesia \\ *Penulis Korespondensi : souisagracia@gmail.com
}

\begin{abstract}
Abstrak
Perma salahan dari kelompok petani sayur di Desa Waiheru, Kecamatan Baguala, Kota Ambon yaitu pengetahuan dan kesadaran yang masih rendah berdampak pada kurangnya perilaku pencegahan dampak akibat penggunaan pestisida seperti kurangnya praktik penggunaan a lat pelindung diri oleh petani ketika melakukan penyemprotan. Tujuan Program Kemitraan Ma syarakat adalah membantu meningkatkan pengetahuan dan pemahaman tentang perilaku pencegahan dampak penggunaan pestisida bagi komunitas petani di Desa Waiheru, pendampingan dalam pembuatan buku panduan/ pedoman perilaku pencegahan dampak pestisida, dan pemeriksaan hemoglobin pada petani sebagai indicator paparan pestisida kimia. Metode yang digunakan adalah pendampingan, penyuluhan/ sosialisasi, pemutaran video, penempelan poster, pemeriksaan hemoglobin. Hasil yang didapatkan a dalah 1). Adanya peningkatan pengetahuan petani ya itu untuk nilaibaik $(\geq 70)$ da ri 8 orang $(66,7 \%$ pretest) menjadi 12 orang (100\% - posttest); 2$)$. sebanyak $3(18,8 \%)$ petani yang mengalami abnormalitas hemoglobin (lebih rendah dari nilai normal); 3 ). Terlaksananya pemutaran video dan pemasangan poster penggunaan APD di Walang Tani. Kesimpulan dari kegiatan ini adalah kegiatan penyuluhan, pemasangan poster, pemutaran video dan pemeriksaan hemoglobin telah meningkatkan pengetahuan petani tentang perilaku pencegahan dampak kesehatan akibat penggunaan pestisida dan memberikan gambaran kesehatan petani.
\end{abstract}

Kata kunci: Pemeriksaan Kesehatan;Penyuluhan; Komunitas Petani.

\begin{abstract}
Community service activities at the vegetable farming community in Waiheru Village, Baguala Subdistrict, Ambon, were carried out based on problems from the partner groups, namely the low level of knowledge and awareness of the impact on the lack of impactprevention behavior due to the use of pesticides from farmers such as misconduct when spraying; lacking of technical guidelines / guidelines on the application of pesticide impact prevention behavior; the existence of health problems in pesticide sprayingfarmers such as itching and nausea after spraying pesticides; also the lacking of practice of using personal protective equipment by farmers when spraying. Farmers need assistance and counseling to increase knowledge. Counseling conducted by agricultural extension has not touched by many aspects of the health of farmers regarding the use of pesticides. The aim of the Community Partnership Program is to help increasing the knowledge and understanding of the behavior of preventing the use of pesticides for the farming community in Waiheru Village, assistance in making manuals / guidelines for preventing pesticide impacts, and examining hemoglobin in farmers as indicators of chemical pesticide exposure. The methods used to achieve the objectives are assistance, counseling / socialization, video screenings, poster placement, hemoglobin examination. The results obtained are 1). An increase in farmers' knowledge is for good grades $\geq 70)$ from 8 people $(66.7 \%$ pretest) to 12 people (100\% - posttest); 2).The amount are 3 (18.8\%)farmers experienced hemoglobin abnormalities (lower than normal values); 3 ). The implementation of video screenings and posters for the use of PPE in Walang Tani. The conclusion is the activities of counseling, posting posters, video screenings and hemoglobin examinations have increased the knowledge of farmers about preventing health effects due to the use of pesticides and provide an overview offarmers' $h e a l t h$.
\end{abstract}

Keywords: Health Check; Counseling; Farming Community.

\section{PENDAhUluan}

Kelompok Sinar Tani merupakan komunitas petani sayur di Desa Wa iheru, berada di Kecamatan Baguala denga jarak $\pm 14 \mathrm{~km}$ dari Universitas Kristen Indonesia
Maluku dan merupakan daerah penghasil sa yur seperti sawi, bayam, kangkung, kacang panjang, buncis, cabe dan lainnya. Hasil wawancara dengan penyuluh pertanian didapatkan bahwa ada beberapa masalah 
terkait yang berhubungan dengan aspek kesehatan da la m perilaku penggunaan pestisida pada petani sayur antara lain kurangnya kesadaran petani tentang penggunaan pestisida sesuai aturan dan kurangnya penggunaan alat pelindung diri ketika melakukan penyemprotan pestisida. Hal ini disebabkan oleh kurangnya informasi tentang dampak pestisida bagi kesehatan petani. Upaya penyuluhan oleh penyuluh pertanian dirasakan kurang efektif ba gi petani karena terbatasnya tenaga dan pendanaan terkait biaya operasional, serta materi penyuluhan yang belum menjelaskan dampak secara spesifik terhadap kesehatan petani. Hasil observasi menunjukan masih a da petani yang tidak menggunakan alat pelindung diri ketika melakukan penyemprotan a tau hanya mengunakan alat pelindung diri seadanya.

Permasalahan yang dialami petani sayur di Desa Waiheru adalah 1). Pengetahuan dan kesa daran yang masih rendah berdampak pada kurangnya perilaku pencegahan dampak akibat penggunaan pestisida; 2). Kurangnya penggunaan APD, dan sikap/ cara yang benar ketika melakukan penyemprotan; 3). Belum adanya panduan/ pedoman teknis penerapan perilaku pencegahan dampak pestisida di Komunitas Kelompok Sinar Tani; 4) Adanya keluhan gangguan kesehatan pada petani penyemprot pestisida seperti ga tal - gatal dan mual setelah melakukan penyemprotan pestisida.

Perlunya peningkatan perilaku pencegahan melalui sosialisasi dan pendampingan dengan harapan memotivasi petani untuk membiasakan dan sadar akan pentingnya perilaku pencegahan bahaya pestisida. Diskusi dengan petani, didapatkan bahwa biasanya petani mengalami gangguan kesehatan seperti ga talgatal dan pusing setelah melakukan penyemprotan. Namun hal ini dianggap bia sa oleh petani karena biasa dialami dan menurut anggapan petani bukanlah penyakit serius. Hasil penelitian Mahyuni (2015) menunjukan bahwa petani penyemprot pestisida di Kecamatan Berastagi berisiko mengalami keracunan pestisida melalui kontak langsung akibat tidak menggunakan pelindung diri yang lengkap dan penggunaan pestisida yang tidak tepat mulai da ri proses penyimpanan, pencampuran, penyemprotan hingga pembuangan pestisida habis pakai sehingga penting untuk memberikan penyuluhan secara berkesinambungan mengenai penggunaan pestisida yang a man dan tepat, penggunaan a lat pelindung diri dan pemeriksaan kesehatan (Mahyuni, 2015).

Pestisida kimia merupakan bahan kimia yang digunakan untuk pengendalian hama atau meminimalkan masalah pada tanaman akibat adanya organisme penganggu tanaman. Salah satu jenis tanaman yang tinggi aplikasi pestisida adalah sayuran. Sebagian besar pestisida diaplikasikan pada tanaman dengan cara penyemprotan. Paparan pestisida menjadi masalah kesehatan masyarakat yang penting di negara berkembang. Penggunaan pestisida secara berlebih sering dilakukan oleh petani, dengan anggapan bahwa semakin banyak pestisida yang digunakan maka semakin ampuh dalam membasmi organisme pengganggu tanaman dan menghemat waktu sehingga dapat meningkatkan jumlah panen dan menambah keuntungan. Penggunaan yang berlebih dapat berpengaruh pada terganggunya kesehatan petani a kibat keracunan secara langsung dan terikutnya residu pestisida yang juga potensial membahayakan kesehatan konsumen. Penggunaan pestisida dapat membahayakan kesehatan diri petani, konsumen serta lingkungan (Wismaningsih dkk, 2016; Rahmawati dkk, 2014; Istianah, 2017; Neupane et 1, 2014).

Perilaku pencegahan bahaya pestisida penting diterapkan oleh petani sehingga dapat mengurangi bahkan menghilangkan risiko keracunan pestisida kimia. Keracunan oleh pestisida terjadi karena terminum, atau terhirup melalui pernapasan atau diserap melalui kulit (Suma'mur, 2009). Menurut Maranata dkk (2014), beberapa faktor y ang dapat mempenganuhi terja dinya keracunan pestisida a dalah faktor ekstemal (dari luar tubuh) seperti banyaknya pestisida yang digunakan, jenis pestisida, dosis pestisida, frekuensi penyemprotan, masa kerja menjadi penyemprot, lama menyemprot, pemakaian alat pelindung diri, cara penanganan pestisida, wa ktu penyemprot dan tindakan terhadap arah angin dan sanitasi dasar. Sedangkan faktor internal (dari dalam tubuh) antara la in umur, jenis kelamin, genetik, sta tus gizi, tingkat pengetahuan dan status kesehatan. Masalah yang umum terjadi adalah masih banyak petani yang mengabaikan hal - hal tersebut diatas karena kurangnya pengetahuan dan kesa daran petani (Maranata dkk, 2014).

Pengetahuan merupakan salah satu faktor pembentuk perilaku. Tinggi rendahnya pengetahuan dapat dipengaruhi oleh proses belajar dan lingkungan. Pengetahuan akan perilaku pencegahan bahaya pestisida bagi petani berdampak pada perilaku petani dan mempen garuhi status kesehatan individu, maupun konsumen. Penelitian yang dilakukan oleh Wisma ningsih dkk (2015), menunjukan ada hubungan antara pengetahuan dengan penggunaan APD pada petani penyemprot di Kecamatan Ngantru, Kabupaten Tulungagung. Penelitian lainnya yang dilakukan oleh Yuantari dkk (2013), menunjukan bahwa pengetahuan yang kurang tepat dalam menggunakan pestisida akan berpengaruh pada perilaku a tau praktik yang kurang tepat pula oleh petani di lahan pertanian. Peningkatan pengetahuan petani akan lebih efektif dengan partisipasi dari petani dan untuk petani dengan cara pemberdayaan masyarakat. Peningkatan pengetahuan mendorong petani untuk menyadari pentingnya cara penggunaan pestisida yang aman, bahaya penggunaan pestisida dan perilaku pencegahan dampak pestisida (Wismaningsih dkk, 2017; Yuantari dkk, 2013).

Salah satu indikator untuk memonitor dampak kera cunan pestisida terhadap petani a dalah pemeriksaan hemoglobin. Hemoglobin merupakan molekul protein yang mengandung zat besi dan merupakan pigmen darah yang membuat darah berwarna merah. Kandungan sulfur yang tinggi di dalam pestisida 
menimbulkan ikatan sulfhemoglobin, yang dapat menyebabkan hemoglobin menjadi tidak nomal dan tidak dapat menjalankan fungsinya dalam mengedarkan oksigen. Ha sil penelitian y ang dilakukan oleh Suryani dkk (2013), menunjukan adanya penurunan kadar hemoglobin pada petani di Desa Riang Gede, Kecamatan Penebel, Tabanan dengan abnormalitas hemoglobin sebanyak 49,3\%. (Rahmawati dkk, 2014; Budia wan, 2014, Cotton et al, 2018).

Bertolak dari situasi diatas, maka penting untuk menerapkan perila ku pencegahan bahaya pestisida bagi komunitas petani. Kondisi yang dialami petani berdasarkan hasil wawancara adalah petani pemah mera sakan mual, pusing dan irita si pa da mata dan kulit setalah melakukan penyemprotan, penggunaan APD juga kurang dipraktikan ka rena terbatasnya APD dan peta ni merasa kurang lelua sa bekerja. Selain itu, petani pun diberi pengetahuan tentang pestisida oleh penyuluh pertanian, namun aspek kesehatan petani belum dijelaskan secara baik. Kegiatan pendampingan, penyuluhan, pemutaran video, dan pemeriksaan hemoglobin dapat menjawab permasalahan tersebut. Adapun tujuan dan manfaat dari kegiatan ini adalah peningkatan pengetahuan dan perilaku penggunaan pestisida yang aman dan sehat.

\section{BAHANDAN METODE}

Untuk menyelesaikan permasalahan mitra yaitu pengetahuan dan kesadaran yang masih rendah dari kelompok tani tentang da mpak pestisida dan perilaku pencegahannya, maka solusi yang dita warkan adalah memberikan pengetahuan dan pemahaman tentang perilaku pencegahan dampak/ penggunaan pestisida yang aman dan sehat dengan menggunakan metode penyuluhan (ceramah, diskusi, tanya jawab). Kegiatan penyuluhan akan dilakukan di Sanggar Ta ni Kelompok Sinar Tani Desa Waiheru, Keca matan Baguala, Kota Ambon.

Permasalahan lain yang dialami mitra yaitu belum adanya panduan sederhana/ pedoman teknis tentang penerapan perilaku pencegahan dampak pestisida dan pengelolaan pestisida, sehingga solusi yang ditawarkan adalah pendampingan petani dalam bentuk Focus Discussion Group untuk merumuskan buku panduan/ pedoman perilaku pencegahan dampak pestisida bagi kesehatan dan penggunaan pestisida yang aman dan sehat. Kegiatan ini akan dilakukan di Sanggar Tani, Desa Waiheru, Kecamatan Baguala, Kota Ambon.

Berda sarkan ha sil observasi dan diskusi dengan ketua kelompok tani dan Dinas Pertanian Kota Ambon, masalah lainnya yang dialami yaitu kurangnya kesadaran dan praktik penggunaan APD oleh petani ketika melakukan penyemprotan pestisida, sehingga perlu memberi contoh penerapan dengan metode pemutaran video antara lain penggunaan APD dan sikap/ cara penyemprotan y ang benar, serta pemasangan poster (penggunaan APD) bagi para petani untuk meminimalkan dampak paparan pestisida kimia bagi petani dan konsumen.
Para petani pun mengeluhkan adanya gatal - gatal pada kulit dan mual ketika selesai melakukan penyemprotan, namun hal tersebut dianggap biasa oleh para petani, untuk itu perlu dilakukan pemeriksaan hemoglobin untuk mengetahui paparan pestisida pada petani. Pemeriksaan hemoglobin dapat dilakukan langsung di lokasi penelitian dengan menggunakan Hemoglobinometer automatic. Hasil pemenksaan disampaikan kepada petani. Kegia tan pengabdian bagi kelompok Sinar Tani dilakukan di Walang Tani, pada bulan Agustus hingga September 2019.

\section{HASIL DAN PEMBAHASAN}

\section{a. Pemeriksaan Kesehatan Petani dan FGD}

Kegiatan ini bertujuan a gar petani dalam kelompok sinar tani mendapatkan gambaran kesehatan khususnya ka dar hemoglobin, hematokrit, a sam urat dan glukosa. Tim pengabdi pun melakukan screening tekanan darah bagi para petani. Kegiatan pemeriksaan kesehatan melibatkan tim PKM, 3 orang mahasiswa dan seorang a nalis kesehatan atau laboran. Kegia tan iniberlangsung pada tanggal 19 September 2019 di Sanggar Tani/ Walang Kelompok Sinar Tani dengan melibatkan 16 orang petani.

Tim berangkat dari UKIM pukul 08.00 WIT, menggunakan 3 unit motor dan membawa berbagai perlengkapan kegiatan seperti spanduk, tensimeter, quick test, dan perlengkapan pemeriksaan kesehatan. Kelompok Sinar Tani telah menyiapkan walang untuk pelaksanaan kegaiatan. Sebelum berangkat dilakukan pertemuan singkat dengan tim untuk membahas teknik pelaksanaan dan pembagian tugas di lokasi. Kegiatan dimulai pukul 09.00 WIT dan petani datang bertahap hingga pemeriksaan selesai dilakukan pada pukul 12.00 WIT. Pa da hari yang sama juga dilakukan sosia lisasi terka it penjualan hasil panen yang diprakarsai olehBank Indonesia, sehingga hanya dapat dila kukan pemenksaan kesehatan dan diskusi singkat dengan petani. Hasil pemeriksaan kesehatan dicatat pada kertas hasil pemeriksaan dan diberikan kepada petani. Hasil pemeriksaan kesehatan dapat dilihat pada tabel benkut :

\section{1) Hemoglobin}

Salah satu indikator untuk memonitor dampak kera cunan pestisida terhadap petani a dalah pemeriksaan hemoglobin. Hemoglobin merupakan molekul protein yang mengandung zat besi dan merupakan pigmen darah yang membuat darah berwarna merah. Kandungan sulfur yang tinggi di dalam pestisida menimbulkan ikatan sulfhemoglobin, yang dapat menyebabkan hemoglobin menjadi tidak nomal dan tidak dapat menjalankan fun gsinya dalam mengedarkan oksigen. Abnormalitas hemoglobin dapat dipenganuhi oleh banyak hal, sehingga tidak spesifik menggambarkan hubungannya dengan paparan pestisida. 
Tabel 1. Ha sil Pemeriksaan Hemoglobin.

\begin{tabular}{|c|l|r|r|}
\hline \multirow{2}{*}{ No Hasil } & \multicolumn{2}{c|}{ Hemoglobin } \\
\cline { 3 - 4 } & & \multicolumn{1}{c|}{ n } & \multicolumn{1}{c|}{$\%$} \\
\hline $\mathbf{1}$ & Normal & 13 & 81.3 \\
\hline $\mathbf{2}$ & Abnormal & 3 & 18.8 \\
\hline & Total & 16 & 100 \\
\hline
\end{tabular}

Tabel 1. menunjukan bahwa sebanyak $3(18,8 \%)$ petani yang mengalami abnomalitas hemoglobin (lebih rendah dari nilai normal). Hasil penelitian yang dilakukan oleh Suryani dkk (2013), menunjukan adanya penurunan kadarhemoglobin pada petani di Desa Riang Gede, Kecamatan Penebel, Tabanan dengan abnormalitas hemoglobin sebanyak 49,3\%.

Keracunan pestisida juga dapat dilihat melalui parameter cholinesterase, semakin rendah kadar cholinesterase maka semakin terdeteksi bahwa petani tersebut mengalami keracunan akibat penggunaan pestisida (Rahmawati dkk, 2014). Penelitian yang dilakukan oleh Budia wan (2014), menunjukan bahwa ada hubungan antara tingkat frekuensi penyemprotan, pemakaian alat pelindung diri, status kesehatan, sikap dan pengetahuan petani dengan cholinesterase pada petani ba wang merah di Ngurensiti Pati. Secara tidak langsung, kegiatan petani yang mengurangi frekuensi menyemprot, menggunakan APD dapat mengurangi terpa parnya petani tersebut dengan pestisida. Cotton et al (2018), menyatakan bahwa Cholinesterase dapat diukur pada sel darah merah/ eritrosit (AChE) dan plasma (PChE).

\section{b. Penyuluhan dan Pemutaran Video}

Kegiatan ini bertujuan agar petani da lam kelompok sinar tani dapat mengetahui dan memahami pentingnya perilaku pencegahan paparan pestisida. Ada berbagai da mpak kesehatan baik akut maupun kronik yang dapat dialami oleh petani dan mengganggu produktivitas sehingga penting untuk melakukan upaya pencegahan dampak pestisida. Kegia tan penyuluhan melibatkan tim PKM, 3 orang mahasiswa. Kegiatan ini berlangsung pada tanggal 21 September 2019 di Sanggar Tanil Walang Kelompok Sinar Tani dengan melibatkan 12 orang petani. Untuk memaksimalkan pemahaman peta ni, maka dilakukan pemutaran video sin gkat tentang jenis APD yang digunakan saat penyemprotan pestisida.

Tim berangkat dari UKIM pukul 09.00 WIT, menggunakan 3 unit motor dan membawa berbagai perlengkapan kegiatan seperti poster, leaflet, pedoman, LCD dan perlengkapan lainnya. Sebelum berangkat dilakukan pertemuan singkat dengan tim untuk membahas teknik pelaksanaan dan pembagian tugas di lokasi. Diarahkan kepada tim untuk melakukan wawancara secara langsung untuk pengisian pre dan post test kepada patani. Kegiatan dimulai pukul 10.00 WIT dan dilakukan wa wancara serta pengisian daftar hadir sambil menunggu petani lainnya. Setelah dilakukan pretest, dilanjutkan deengan penyuluhan tentang upaya pencegahan dampak pestisida dengan media leaflet dan penayangan materi serta video melalui LCD. Petani memperhatikan dengan baik bahkan merespon bahwa pernah mengalami irita si pada mata dan kulit setelah gunakan pestisida, juga lalai dalam penggunaan Alat Pelindung Diri (APD) ketika melakukan pencampuran dan penyemprotan pestisida. Petani mengeluhkan kurangnya sosialisasi terkait dampak kesehatan sehingga kurang memahami akibat yang ditimbulkan jika tidak menggunakan pestisida sesuai aturan dan tidak gunakn APD. Diskusi diakhii dengan post test yang juga dilakukan dengan menanyakan secara langsung ke petani. Hasil pre dan post test kemudian diperiksa oleh tim dan didapatkan hasil sebagai berikut :

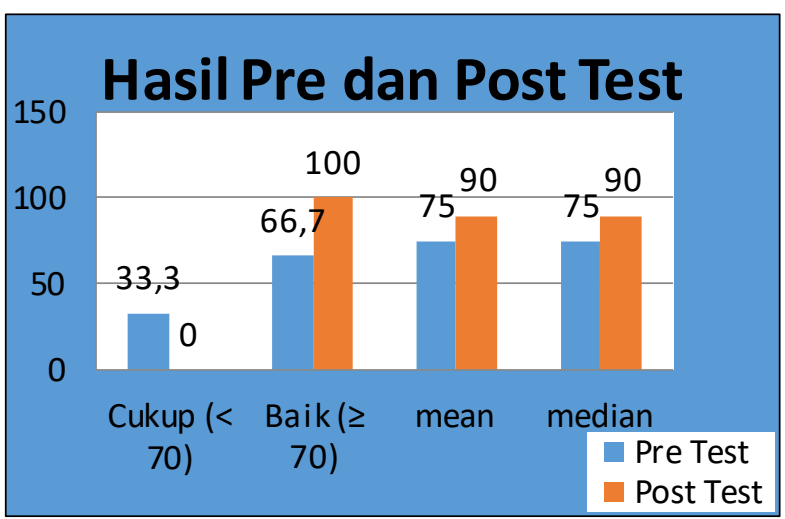

Grafik 1. Hasil Pre dan Post Test.

Grafik 1 menunjukan bahwa setelah dilakukan penyuluhan, pengetahuan petani mengalami peningkatan yaitu untuk nila i baik $(\geq 70)$ dari 8 orang ( $66,7 \%$ - pretest) menjadi 12 orang ( $100 \%$ - posttest). Sedangkan nilai mean dan median meningkat dari 75 menjadi 90. Hal ini menunjukan bahwa terjadi peningkatan pengetahuan pada petani setelah diberikan penyuluhan dengan menggunakan metode ceramah dan media leaflet. Pengetahuan akan perilaku pencegahan dampak pestisida yaitu dimulai dari 1) saat pembelian pestisida; 2). Membaca label produk; 3). Mengangkut dan menyimpan pestisida dengan benar; 4). Tindakan sa at sprayer tersumbat; 5). Sa at mencampur pestisida; 6). Saat menggunakan pestisida; 7). APD dalam penggunaan pestisida; 8). Tatalaksana sisa pestisida. Selain hasil pre dan post test dengan kategori baik dan cukup, tim pengabdi pun melakukan a nalisis butir soal dengan mengoreksi jawaban benar dan salah untuk mengetahui pernyataan yang masih keliru dijawab oleh petani.

Hasila nalisis butirsoal (koreksi jawaban yang salah dan benar), diurutkan 3 persentase terbesar untuk jawaban keliru dari petani, didapatkan bahwa 1). Sebanyak 8 $(66,7 \%)$ dari 12 petani yang sa lah menjawab pada jenis APD ketika menyemprot, petanimemahamijenis APD yang wajib digunakan hanya masker dan sa rung tangan; 2). Sebanyak $6(50 \%)$ petani yang masih memahami pestisida sebagai "obat" bagi tanaman. Pestisida harus dipahami petani sebagai racun bagi hama tanaman sehingga lebih waspada dalam menggunakan pestisida dan 3). Sebanyak $5(41,7 \%)$ petani yang kelinu 
menjawab pernyataan tentang penggunaan pestisida yang tidak sesuai aturan, berbahaya bagi kesehatan.

Hasil post test, masih ditemukan persentase tertinggi untuk jawaban yang masih keliru dari petani yaitu terka it APD yang hanya terdiri dari masker dan sanung tangan yaitu sebanyak $4(33,3 \%)$ petani. Pada sesi diskusi, petani mengungkapkan bahwa masih belum memperhatikan atau lalai dalam menggunakan kelengkapan APD yang terdiri dari penutup kepala, kaca mata, pelindung pernafasan, baju dan celana kerja lengan panjang, sarung tangan dan sepatu. Petani mengakui bahwa pernah terja di iritasi pada mata dan ku lit a kibat la lai menggunakan APD secara lengkap.

Penerapan penyuluhan tentang bahaya pestisida bagi kesehatan petani di Waiheru, Kota Ambon dapat mendukung praktik pencegahan dampak pestisida. Hasil penelitian Mahyuni (2015), menunjukan pentingnya memberikan penyuluhan secara berkesinambungan mengenai penggunaan pestisida yang a man dan tepat, penggunaan alat pelindung diri dan pemeriksaan kesehatan, hal ini didasarkan pada kondisi petani penyemprot pestisida di Kecamatan Berastagi berisiko mengalami keracunan pestisida melalui kontak langsung akibattidak menggunakan pelindung diri yang lengkap dan penggunaan pestisida yang tidak tepat mulai dari proses penyimpanan, pencampuran, penyemprotan hingga pembuangan pestisida habis pakai sehingga (Mahyuni, 2015).

\section{KESIMPULAN}

Kesimpulan dari kegiatan ini adalah (1). Adanya peningkatan pengetahuan petani yaitu untuk nilai baik $(\geq 70)$ dari 8 orang $(66,7 \%$ - pretest $)$ menjadi 12 orang (100\% -posttest); (2). sebanyak $3(18,8 \%)$ petaniyang mengalami abnormalitas hemoglobin (lebih rendah dari nila i normal); (3). Terlaksananya pemutaran video dan pemasangan poster penggunaan APD di Wa lang Tani. Kegiatan penyuluhan dapat berjalan berkelanjutan secara mandiri, melalui pedoman pencegahan bahaya pestisida yang telah disusun bersama oleh kelompok tani dan tim pengabdi.

\section{UCAPAN TERIMA KASIH}

Ucapan terima ka sih disa mpaikan kepada Rektor dan Lembaga Pengabdian Kepada Masyarakat, Universitas Kristen Indonesia Maluku atas dukungan pendanaan melalui program Pengabdian Kepada Masyarakat (unggulan). Terima kasih juga disampaikan kepada ketua dan anggota kelompok SinarTani, Desa Waiheru, Kota Ambon, a tas kerjasama y ang tela h terjalin dengan tim pengabdi.

\section{DAFTAR PUSTAKA}

Budiawan, R.A. (2014). Faktor Risiko yang Berhubungan dengan Cholinesterase pada Petani
Bawang Merah di Ngurensiti Pati. Unnes Journal of Public Health, 3(1), 1-11.

Cotton, J., Edwards, J., Rahman, M. A., \& Brumby, S. (2018). Cholinesterase Research Outreach Project (CROP) : Point of Care Cholinesterase Measurement in an Australian Agricultural Community. Environmental Health, 17(31), 111.

Istianah., \& Yunia stuti, A. (2017). Hubungan Masa Kerja, Lama Menyemprot, Jenis Pestisida, Pengunaan Pestisida dan Pengelolaan Pestisida dengan Kejadian Keracunan pada Petani di Brebes. Public Health Perspective Journal, 2(2), 117-123

Mahyuni, E.L. (2015). Faktor Risiko dalam Penggunaan Pestisida Terhadap Keluhan Kesehatan pada Petani di Kecamatan Berastagi Kabupaten Karo 2014. Jurnal Kemas, 9(1),79-89.

Maranata, R., Chahay, I., \& Santi, D.N., (2014). Perilaku Petanidalam Penggunaan Pestisida dan Alat Pelindung Diri serta Keluhan Kesehatan Petani di Desa Suka Julu Kecamatan Barus Jahe Kabupaten Karo Tahun 2014. Jurnal Lingkungan dan Keselamatan Kerja, 3(3), 1-7.

Neupane, D., Jors, E., \& Brandt, L. (2014). Pesticide Use, Erythrocyte Acetylcholinesterase Level and Self-Reported Acute Intoxication Symptoms Among Vegetable Farmers in Nepal: a crosssectional study. Environmental Health, 13(98), 1-7.

Rahmawati, D. Y., \& Martiana, T. (2014). Penganuh Faktor Karakteristik Petani dan Metode Penyemprotan Terhadap Kadar Cholinesterase. The Indonesian Journal of Occupational Safety, Health and Environment, 1(1), 85 - 94.

Suma'mur. (2009). Higiene Perusahaan dan Kesehatan Kerja (Hiperkes).Jakarta: CV Sagung Seto.

Suryanhi, M.A.H., Suryadhi, P.A.R., \& Purnama, G.H., (2013). Penggunaan Alat Pelindung Diri (APD) dan Kadar Hemoglobin pada Petani Pengguna Pestisida di Desa Riang Gede, Kecamatan Penebel, Tabanan. Arc.Com.Health, 2(2), 112116

Wismaningsih, E.R., \& Oktaviasari, D. I. (2016). Identifikasi Jenis Pestisida dan Penggunaan APD pada Petani Penyemprot di Kecamatan Ngantru Kabupaten Tulungagung. Jurnal Wiyata, 3(1), $100-105$.

Yuantari, MG.C., Widiarnako, B., \& Sunoko H.R (2013). Tingkat Pengetahuan Petani dalam Menggunakan Pestisida (Studi Kasus di Desa Curut Kecamatan Penawangan Kabupaten Grobogan) pada Seminar Nasional Pengelolaan Sumberdaya Alam dan Lingkungan (pp. 142148). Semarang, Indonesia: Program Pasca Sarjana Ilmu Lingkungan, Universitas Diponegoro. 